\title{
HAND HYGIENE AND PERSONAL PROTECTIVE EQUIPMENT IN HEALTHCARE SETTINGS DURING COVID-19 PANDEMIC IN BANGLADESH
}

\author{
MD REZAUL KARIM ${ }^{1-2^{*}}$, SUSHIL KUMAR SAH ${ }^{3}$, AFSARUNNESA SYEDA ${ }^{4}$, MUHAMMAD TANVIR FAYSOL $^{5}$, \\ AMINUR RAHMAN ${ }^{6}$, KHALEDA ISLAM $^{2}$, MD NIZAMUL HOQUE BHUIYAN ${ }^{2}$, MOHD MOZIBOR RAHMAN ${ }^{7}$
}

\begin{abstract}
:
Objective: This study conducted to implement protective measures in healthcare settings during the COVID-19 pandemic in the context of Bangladesh.

Methods: It is an observational survey study. A pre-designed open questionnaire electronic link using google form was used to collect data from 500 healthcare workers within Bangladesh in which participants were observed, and variables were measured.

Results: The study findings revealed that among all participants, 70.9\% were working in COVID-19 dedicated hospitals, and 1.8\% were diagnosed with COVID-19 while working. The study showed that 69.1\% of participants washed hands before and after consulting/handling each patient, 69.1\% had readily available rubs/sanitizer in their healthcare facility, and $65.5 \%$ adhered principals of handwashing. The study also revealed that only $76.4 \%$ of participants maintained aseptic precautions for donning/doffing.
\end{abstract}

Conclusion: The study findings recommend that mandatory training and maintaining aseptic precautions for PPE putting on (donning), and removal (doffing) is equally important.

Keywords: COVID-19; SARS-CoV-2; Hand Hygiene; Personal Protective Equipment; Healthcare Settings; Bangladesh.

Received: 11 May 2020

Accepted: 12 June 2020

DOI: https://doi.org/10.3329/bjm.v31i2.48535

\section{Introduction}

Coronavirus disease 2019 (COVID-19), caused by the severe acute respiratory syndrome coronavirus 2 (SARS-CoV-2), was first detected in city Wuhan, China, in December 2019. On 30 January 2020, the World Health Organization (WHO) declared that this outbreak constituted a public health emergency of international concern. On 11 March 2020, WHO has announced the novel coronavirus (COVID-19) outbreak, a worldwide pandemic. COVID-19 is spread by droplets infection. ${ }^{1-2}$ It shows that this virus is extremely infectious and spreads mostly who are come in contact. Maintaining good hand hygiene in healthcare workers is fundamental to infection prevention yet remains a challenge to keep up, particularly in developing countries like Bangladesh.

Hand washing is one in each of those basic items which we never expect to be asked about, and it's proven in controlling the infectious disease like this. ${ }^{3-4}$ Personal protective equipment (PPE) has become a crucial and sensitive subject during this COVID-19 pandemic. COVID-19 spreads predominantly by large respiratory particles such as a droplet, close contact, or perhaps aerosol transmission, which are subject to gravitational forces and travel approximately 2 meters from the patient. ${ }^{5}$ These aerosols contain particles that vary and

1. Hubei Key Laboratory of Embryonic Stem Cell Research, Institute of Neuroscience, Hubei University of Medicine, Shiyan, China.

2. Institute of Nutrition and Food Science, University of Dhaka, Dhaka, Bangladesh.

3. Department of Otorhinolaryngology, Hubei University of Medicine, Shiyan, China.

4. Department of Obstetrics and Gynaecology, Renmin Hospital, Hubei University of Medicine, Shiyan, China.

5. Department of Internal Medicine, Holy Family Red Crescent Medical College Hospital, Dhaka, Bangladesh.

6. Department of Neurology, Sir Salimullah Medical College Hospital, Dhaka, Bangladesh.

7. Department of Neuromedicine, Combined Military Hospital, Dhaka, Bangladesh.

Address of Correspondence: Dr. Md Rezaul Karim, MBBS, MD; Hubei Key Laboratory of Embryonic Stem Cell Research, Institute of Neuroscience, Hubei University of Medicine, 30 South Renmin Road, Shiyan, Hubei 442000, China. Email: dr_mdrezaulkarim@hotmail.com 
may travel more than 2 meters and remain airborne for a prolonged period, depending upon the weather conditions. Still, their chance of getting transmission is unclear. Contact droplets and transmission mechanisms are relevant during airway maneuvers such as tracheal intubation in infected patients.

Personal protective equipment such as gloves, face masks, boots, earplugs, goggles, hard hats, thin protective clothing, respirators, safety shoes are essential components, but only one aspect of a system, protecting staff and other patients from COVID-19 cross infection. ${ }^{6}$ Appropriate use of PPE significantly reduces the danger of viral transmission. Personal protective equipment should be up to the noble standards to stop the transmission from patient carecontact, droplet, or airborne. Recommendations from international organizations are specified different protective tools, but the proper technique to use equipment isn't much highlighted. Uncertainty remains around specific details of protective equipment, including hoods, gloves, mask type, and the potential for re use of PPE kit. Moreover, preventing transmission of this deadly COVID - 19 virus requires two major things: make availability of high standard PPE and appropriate technique to use this equipment by our frontline healthcare workers. Without proper Hand hygiene and proper use of PPE, it's impossible to scale back the danger of infections, especially in frontline healthcare workers.

\section{Methodology \\ Study design}

It is an observational survey study, where we used a pre-designed open questionnaire to collect data from healthcare workers within Bangladesh, where we observed the participants and measured variables. This study neither influenced nor intervened in the study participant in any way. Collected data were simply gathered, and correlations were investigated without manipulation by the investigators.

Ethical consideration and approval, informed consent The study was carried out in accordance with the recommendation of the Institutional Review Board (IRB), and the project was approved by the Hubei University of Medicine, Shiyan, Hubei 4000, China. The study was carried out in multiple healthcare workers' Facebook groups within Bangladesh, using an open questionnaire, which included a consent statement to participate at the top of the form "Note: Please fill all the questionnaire if you agree to participate in this research." Only those agreed to participate were able to submit the open questionnaire for data collection.

\section{Data collection}

An open questionnaire electronic link was established using google form on hand hygiene and personal protective equipment-related information. The form was then posted to multiple healthcare workers' Facebook groups within Bangladesh. Doctors, nurses, and lab technicians were included as the participants in this study. Once the google form was filled and submitted by each participant agreeing to the open questionnaire's consent statement, data were automatically collected. To conclude, a total of 500 responses were received.

\section{Data analysis}

Once the data were automatically collected via the electronic questionnaire link established using the google form, they were analyzed using the "publish analytics" tool of the form section. Analyzed data were used to describe the shortcomings of hand hygiene and personal protective equipment in Bangladesh's healthcare settings.

\section{Results}

\section{Demographic characteristics}

The demographic findings (see Table 1 and Figure 1) revealed that most of the participants were doctors, $76.4 \%$ (doctors), $16.4 \%$ (nurses), and $7.3 \%$ (lab technicians). Among these participants, 70.9\% (were working in COVID-19 dedicated hospital), 25.5\% (were not working in COVID-19 dedicated hospital), and 3.6\% (were unsure whether their workplace was COVID-19 dedicated or not). 1.8\% (were COVID-19 diagnosed), 90.9\% (were healthy), and $7.3 \%$ (participants had COVID-19 related symptoms but were not diagnosed).

\section{Hand hygiene-related maintenance}

The study findings on hand hygiene-related maintenance (see Table 2 and Figure 2) revealed a record number of differences among healthcare workers. Frequency of sanitizing/wash hands was $69.1 \%$ (before and after consulting/ handling patients), $27.3 \%$ (only after consulting/handling each patient), and $20.0 \%$ (before and after the use of gloves); whereas materials used for handwashing $50.9 \%$ (plain soap), $20.0 \%$ (antiseptic soap), and $43.6 \%$ (antiseptic solution). Among all the participants 65.5\% (adhered principals of handwashing), $3.6 \%$ (did not adhere principals of handwashing), and $30.9 \%$ (sometimes adhered principals of handwashing); whereas $54.5 \%$ (preferred alcohol rubs over handwashing), 36.4\% (did not prefer alcohol rubs over handwashing), and $9.1 \%$ (preferred alcohol-based rubs after handwashing). Also, $69.1 \%$ (had readily available rubs/sanitizer in their healthcare facility), 9.1\% (did not have readily available rubs / sanitizer in their healthcare facility), and $21.8 \%$ (used personal hand rub/sanitizer even though their healthcare facility had available rubs/sanitizer). 


\section{PPE-related maintenance}

The study findings on PPE-related maintenance (see Table 3 and Figure 3) also revealed a record number of differences among healthcare workers and healthcare facilities. At the participant's workplace 61.8\% (used PPE), 5.5\% (did not use PPE), and 32.7\% (used mask and gloves only) as protective equipment while working, and materials included in PPE were 16.4\% (mask and gloves), 32.7\% (gown, mask, and gloves), and 50.9\% (gown, mask, gloves, goggles and/ or face shield). $76.4 \%$ (participants maintained aseptic precautions for donning/doffing), 5.5\% (participants did not maintain aseptic precautions for donning/ doffing), and $18.2 \%$ (participants occasionally maintained aseptic precautions for donning/doffing).
Among all the participants, their mask type included were $45.5 \%$ (N95 or FFP2 respirator), 45.5\% (surgical mask), and 9.1\% (other available mask types). Additionally, 40.0\% (participants healthcare facility had an available room for PPE donning/doffing), 58.2\% (participants healthcare facility did not have available room for PPE donning/doffing), and 1.8\% (participants stated availability but did not prefer to use it for PPE donning/doffing). Nonetheless, all the participants did not receive institutional training for PPE donning/ doffing as revealed in this study $60.8 \%$ (received institutional training for PPE donning/doffing), 17.6\% (did not receive institutional training for PPE donning/ doffing), and $21.6 \%$ (participants did self-learning from non-institutional/other sources).

Table-I

Demographic characteristics data of participants

\begin{tabular}{lll}
\hline Professions of participants & $\begin{array}{l}\text { COVID-19 dedicated hospital as } \\
\text { a working unit of participants }\end{array}$ & $\begin{array}{l}\text { Participants diagnosed with } \\
\text { COVID-19 while working }\end{array}$ \\
\hline $76.4 \%$ (doctors) & $70.9 \%$ (yes) & $1.8 \%$ (yes) \\
$16.4 \%$ (nurses) & $25.5 \%$ (no) & $90.9 \%$ (no) \\
$7.3 \%$ (lab technicians) & $3.6 \%$ (not known) & $7.3 \%$ (participants have related \\
& & symptoms but not yet diagnosed) \\
\hline
\end{tabular}

Table-II

Hand hygiene-related maintenance data among participants

\begin{tabular}{|c|c|c|c|c|}
\hline $\begin{array}{l}\text { Frequency of } \\
\text { sanitizing/wash } \\
\text { hands }\end{array}$ & $\begin{array}{l}\text { Wash hands } \\
\text { materials }\end{array}$ & $\begin{array}{l}\text { Adhere, } \\
\text { principles of } \\
\text { handwashing, }\end{array}$ & $\begin{array}{l}\text { Preference of } \\
\text { alcohol rubs over } \\
\text { handwashing }\end{array}$ & $\begin{array}{l}\text { Readily available } \\
\text { rubs/sanitizer in } \\
\text { healthcare facility }\end{array}$ \\
\hline $\begin{array}{l}69.1 \% \text { (before and } \\
\text { after consulting/ } \\
\text { handling patients) }\end{array}$ & $\begin{array}{l}50.9 \% \text { (plain } \\
\text { soap) }\end{array}$ & $65.5 \%$ (yes) & $54.5 \%$ (yes) & $69.1 \%($ yes $)$ \\
\hline $\begin{array}{l}27.3 \% \text { (only after } \\
\text { consulting/handling } \\
\text { each patient) }\end{array}$ & $\begin{array}{l}20.0 \% \text { (antiseptic } \\
\text { soap) }\end{array}$ & $3.6 \%(\mathrm{no})$ & $36.4 \%$ (no) & $9.1 \%(\mathrm{no})$ \\
\hline $\begin{array}{l}20.0 \% \text { (before and } \\
\text { after the use of } \\
\text { gloves) }\end{array}$ & $\begin{array}{l}43.6 \% \text { (antiseptic } \\
\text { solution) }\end{array}$ & $\begin{array}{l}30.9 \% \\
\text { (sometimes) }\end{array}$ & $\begin{array}{l}9.1 \% \text { (prefer } \\
\text { alcohol-based rubs } \\
\text { after handwashing) }\end{array}$ & $\begin{array}{l}21.8 \% \text { (use } \\
\text { personal hand } \\
\text { rub/sanitizer) }\end{array}$ \\
\hline
\end{tabular}

Table-III

PPE-related maintenance data among participants

\begin{tabular}{|c|c|c|c|c|c|}
\hline $\begin{array}{l}\text { Participants } \\
\text { use PPE at } \\
\text { workplace } \\
\end{array}$ & $\begin{array}{l}\text { Participants } \\
\text { PPE materials } \\
\text { included }\end{array}$ & $\begin{array}{l}\text { PPE aseptic } \\
\text { precautions for } \\
\text { donning/doffing }\end{array}$ & $\begin{array}{l}\text { Participants } \\
\text { mask type } \\
\text { included } \\
\end{array}$ & $\begin{array}{l}\text { Available room } \\
\text { for PPE } \\
\text { donning/doffing }\end{array}$ & $\begin{array}{l}\text { Institutional } \\
\text { training for PPE } \\
\text { donning/doffing }\end{array}$ \\
\hline $61.8 \%$ (yes) & $\begin{array}{l}16.4 \% \text { (mask } \\
\text { and gloves) }\end{array}$ & 76.4\% (yes) & $\begin{array}{l}45.5 \% \text { (N95 } \\
\text { or FFP2 respirator) }\end{array}$ & $40.0 \%$ (yes) & $60.8 \%$ (yes) \\
\hline $5.5 \%$ (no) & $\begin{array}{l}32.7 \% \text { (gown, } \\
\text { mask and gloves) }\end{array}$ & $5.5 \%$ (no) & $\begin{array}{l}45.5 \% \\
\text { (surgical mask) }\end{array}$ & $58.2 \%$ (no) & $17.6 \%$ (no) \\
\hline $\begin{array}{l}32.7 \% \text { (mask } \\
\text { and gloves } \\
\text { only) }\end{array}$ & $\begin{array}{l}50.9 \% \text { (gown, } \\
\text { mask, gloves, } \\
\text { goggles and/or } \\
\text { face shield) }\end{array}$ & $\begin{array}{l}18.2 \% \\
\text { (sometimes) }\end{array}$ & $\begin{array}{l}9.1 \% \text { (any } \\
\text { other mask) }\end{array}$ & $\begin{array}{l}1.8 \% \\
\text { (available, not } \\
\text { do not prefer to } \\
\text { use it) }\end{array}$ & $\begin{array}{l}21.6 \% \text { (self- } \\
\text { learning from } \\
\text { non-institutional/ } \\
\text { other sources) }\end{array}$ \\
\hline
\end{tabular}




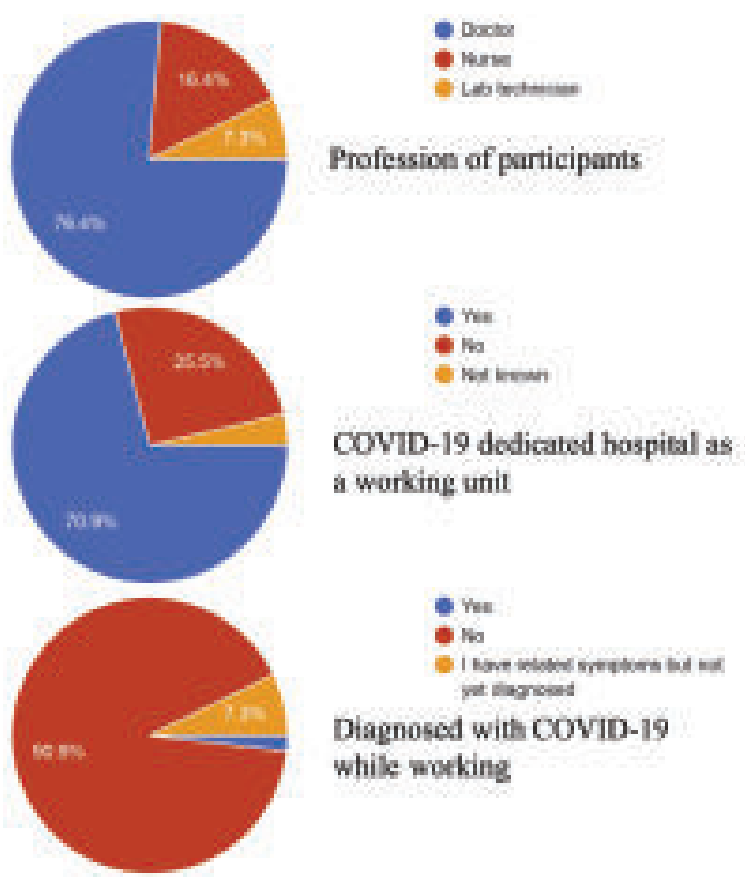

Fig.-1: Demographic characteristics of participants

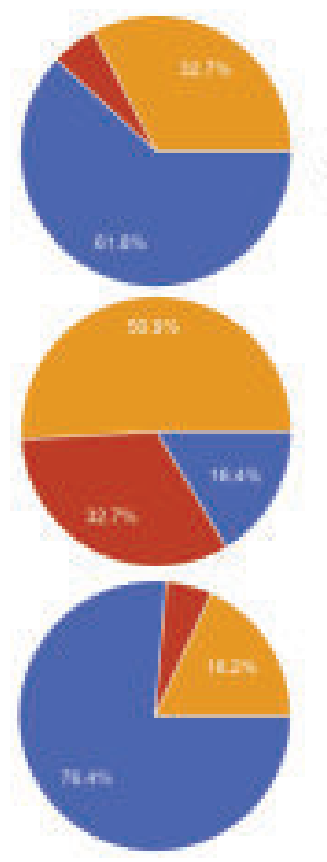

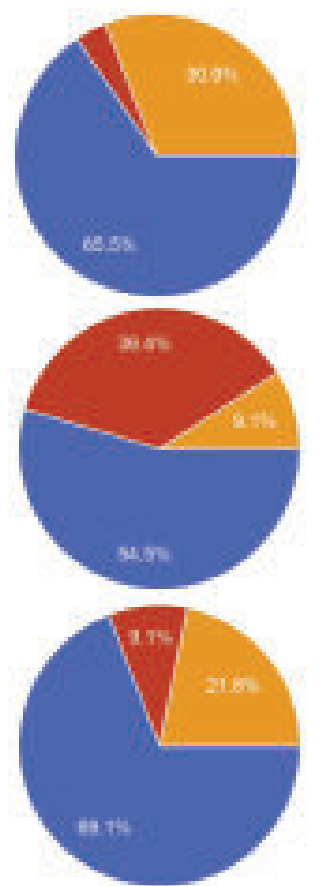

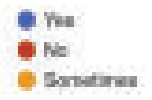

Adhere principles of handwushing

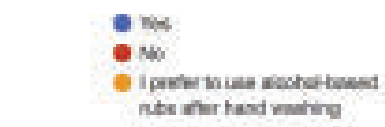

Prefer alcohol nubs over bandwashing

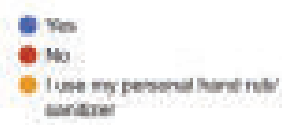

Readily available nabs/sanitizer in bealtheare facility

Fig.-2: Hand hygiene-related maintenance among participants

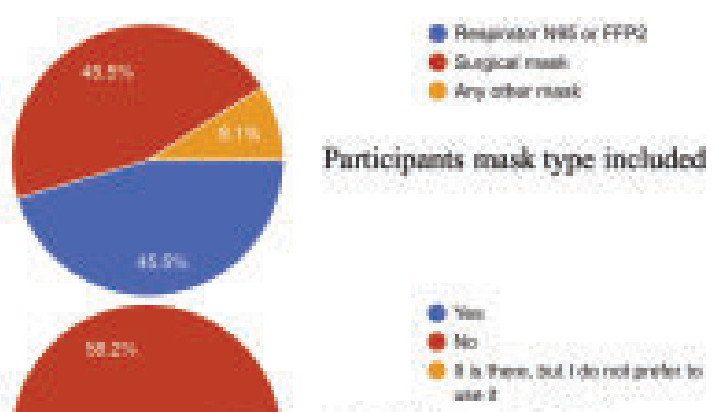

Available room for PPE

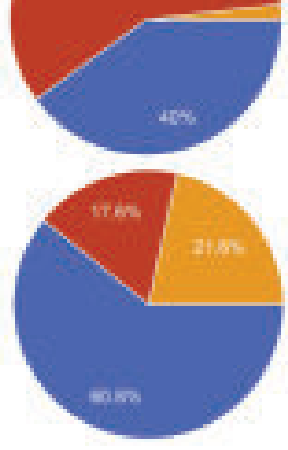

donning/doffing at workplace

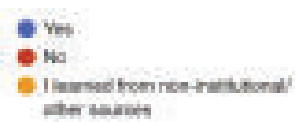

Institutional training for PPE dotming/doffing

Fig.-3: PPE-related maintenance among participants

\section{Discussions}

Thousands of people died around the globe from infections acquired while receiving health care. Hand hygiene is the foremost important measure to avoid the transmission of harmful germs and prevent healthcare-associated infections. These things even become more crucial after we discuss the developing world. There are numerous reasons why healthcare workers are unable to maintain good hand hygiene within the hospital sector. The foremost important factor is the shortage of PPE and proper techniques for using PPE while handling the patient. WHO 
recommends that healthcare workers wash their hands before touching a patient, before cleaning/aseptic procedures, after exposure/risk, after touching a patient, and after touching the patient's surroundings. As infection-causing pathogens can live to inform the story one's body and within the encircling environment. Hence more practical interventions should be encouraged for personal-hygiene.

Healthcare professionals' hands are the typical leading vehicle for transmitting healthcare-associated pathogens from patient to patient and patient to healthcare professionals and within the healthcare environment. ${ }^{7}$ Hand hygiene is a crucial measure for preventing the spread of pathogens and reducing healthcare-associated infections. ${ }^{8}$ Still, healthcare professional's compliance with optimal practices remains low in most settings, especially developing country, where improper hand hygiene while handling the patient has been practiced frequently and thus becomes an easy route for transmission of this deadly virus COVID-19.9-10 The main objective of the first global patient safety challenge, launched by the WHO, is to realize an improvement in hand hygiene practices worldwide with the ultimate word goal of promoting a sturdy patient safety culture. The varied strategies proposed within the WHO guidelines readily available hygiene in health care. ${ }^{11}$

On the other hand, personal protective equipment is clothing, or equipment designed to safeguard healthcare workers from the chance of injury or illness. PPE can include protective clothing, helmets, goggles, or other garments or equipment. These are necessary tools for healthcare workers to prevent the transmission of pathogens and stop crosstransmission. PPE includes a serious limitation that it doesn't eliminate the pathogens at the source and will end in healthcare workers being exposed to the pathogens if the equipment fails or faulty. PPE may be a hot topic, probably the foremost discussed and controversial subject for frontline healthcare staff working with patients with COVID 19. As this COVID19 is already declared an outbreak by WHO, and each day thousands of peoples getting this disease, including our frontline healthcare workers everywhere on the globe.

The maximum viral load of SARS CoV 2 is in sputum, and upper airway secretions, whereas blood borne infection, isn't considered a significant source of transmission. ${ }^{12}$ The virus is especially spread by droplets and different contact routes. ${ }^{13}$ Transmission occurs through droplet particles bigger than $5 \mu \mathrm{m}$ diameter, mainly respiratory particles. These unlikely to travel quite 1 -meter, therefore a 2 -meter margin on contact is safety. Contact transmission occurs because once the virus is on a surface, it'll remain there and can be a possible source of infection for hours or maybe days. ${ }^{14}$ This makes the danger that healthcare workers touching that surface will become contaminated, and subsequently, they, or others, will become infected. The transmission mechanism is seen when smaller respiratory particles (generally $<5 \mu \mathrm{m}$ ) circulate within the air for prolonged periods. Usually, viral particles are absorbed via the respiratory mucosa and potentially across the conjunctivae. Particles smaller than $10 \mathrm{im}$ are presumably to breach deeply into the lung and cause infection. ${ }^{15}$ The coronavirus isn't currently considered an airborne virus, so airborne precautions don't seem to be frequently necessary. ${ }^{13}$ However, specific procedures, mainly those associated with airway management, can create aerosols containing viruses that remain within the air and thus risk transmission over distances beyond 2 meters.

Various organizations have produced guidance on PPE which is broadly consistent, including the world health organization. ${ }^{16}$, the EU center for disease control, ${ }^{17}$ Public Health England 2, and also, the European society of medical aid medicine and society of critical care medicine. ${ }^{18}$ Each organization states that airborne precautions include fit tested and fit checked high filtration masks, goggles or visor, long-sleeved fluid repellent gown, and gloves. Guidelines include the employment of FFP2 masks, ${ }^{16-17,19}$ although few currently only sit down with FFP3 masks. ${ }^{13}$

Nonetheless, personal protective equipment should be disposable soon, accurately, and instantly after removal. There should be an observer employing a checklist ensuring donning and doffing of PPE is performed correctly. Training and practicing PPE use before and after patient care is mandatory for healthcare workers and patient safety. Hence, all the healthcare workers exposed daily to those viruses must protect themselves by using PPE like respirators, clothes, goggles, surgical cap, and face mask. In this research, we analyzed hand hygiene factors and personal protective equipment compliance in healthcare settings in Bangladesh using an open questionnaire to healthcare workers. The results show highly consistent with other researches. ${ }^{20-22}$ Furthermore, without adequate and high-quality PPE, healthcare workers are at higher risk of getting infected. ${ }^{23}$

\section{Conclusion}

Hand hygiene and personal protective equipment in healthcare settings during the COVID-19 pandemic are incredibly crucial. Hands are the foremost pathways of germ transmission during health care and 
could be a vital public health concern. Nonetheless, personal protective equipment should be accessible to get rid of after use without contaminating the user. Therefore, the following recommendations could help improve hand hygiene and PPE in healthcare settings in Bangladesh. (1) Adhere to principles of handwashing and increase the frequency of sanitizing/wash hands. (2) Maintain aseptic precautions and arrange for mandatory training for PPE donning and doffing to all healthcare workers. (3) Assure the quality of PPE in healthcare settings to avoid cross-transmission. This study represents a minuscule of a larger sample. However, further research is required in a larger sample, to evaluate each strategy component's relative efficacy and identify the foremost appropriate interventions, particularly in healthcare settings, with limited resources.

\section{Conflict of Interests}

None to declare.

\section{Authors' Contributions}

MRK: concept development, review plan, data collection, data analysis, manuscript writing, review, and editing of the manuscript. SKS, and AS: data collection, review, and manuscript writing. MTF, and AR: data collection and review of the manuscript. KI, MNHB, and MMR: critical review and editing of the manuscript.

\section{Declaration}

All the authors approved to publish this work.

\section{Funding}

Not applicable.

\section{References}

1. World Health Organization. (2020). Critical preparedness, readiness and response actions for COVID-19: interim guidance. World Health Organization, 2020.

2. Wu, Y., Chen, C., \& Chan, Y. (2020). The outbreak of COVID-19. Journal of the Chinese Medical Association, 83(3), 217-220. https://doi.org/10.1097/JCMA. 0000000000000270. PMid:32134861 PMCid:PMC 7153464

3. Aiello, A. E., Coulborn, R. M., Perez, V., \& Larson, E. L. (2008). Effect of hand hygiene on infectious disease risk in the community setting: A meta-analysis. American Journal of Public Health, 98(8), 1372-1381. https:// doi.org/10.2105/ajph.2007.124610. PMid:18556606 PMCid:PMC2446461

4. Aiello, A., Murray, G., Perez, V., Coulborn, R., Davis, B., Uddin, M., Shay, D., Waterman, S., \& Monto, A. (2010). Mask use, hand hygiene, and seasonal influenza like illness among young adults: A randomized intervention trial. The Journal of Infectious Diseases, 201(4), 491-498. https://doi.org/10.1086/650396. https://doi.org/10.1086/650396. PMid:20088690

5. Salemi, C., Canola, M. T., \& Eck, E. K. (2002). Hand washing and physicians: How to get them together. Infection Control \& Hospital Epidemiology, 23(1), 3235. https://doi.org/10.1086/501965. https://doi.org/ 10.1086/501965. PMid:11868890

6. Setti, L., Passarini, F., De Gennaro, G., Barbieri, P., Perrone, M. G., Borelli, M., Palmisani, J., Di Gilio, A., Piscitelli, P., \& Miani, A. (2020). Airborne transmission route of COVID-19: Why 2 meters 6 feet of interpersonal distance could not be enough. International Journal of Environmental Research and Public Health, 17(8), 2932. https://doi.org/10.3390/ijerph17082932. PMid:32340347 PMCid:PMC7215485

7. Verbeek, J. H., Rajamaki, B., Ijaz, S., Sauni, R., Toomey, E., Blackwood, B., Tikka, C., Ruotsalainen, J. H., \& Kilinc Balci, F. S. (2020). Personal protective equipment for preventing highly infectious diseases due to exposure to contaminated body fluids in healthcare staff. Cochrane Database of Systematic Reviews. https://doi.org/10.1002/14651858.CD011621.pub4. PMid:32293717

8. Gupta, A., Patil, V., Todi, S., Ramasubban, S., Myatra, S. N., Samaddar, D. P., \& Bhattacharya, P. K. (2014). Guidelines for prevention of hospital acquired infections. Indian Journal of Critical Care Medicine, 18(3), 149-163. https://doi.org/10.4103/09725229.128705. https://doi.org/10.4103/09725229.128705. PMid:24701065 PMCid:PMC3963198

9. Mitchell, A., Spencer, M., \& Edmiston, C. (2015). Role of healthcare apparel and other healthcare textiles in the transmission of pathogens: A review of the literature. Journal of Hospital Infection, 90(4), 285-292. https:/ / doi.org/10.1016/j.jhin.2015.02.017. PMid:25935701 PMCid:PMC7132459

10. World Health Organization. (2020). Infection prevention and control during health care when COVID-19 is suspected: interim guidance. World Health Organization, 2020.

11. World Health Organization. (2020). Rational use of personal protective equipment (PPE) for coronavirus disease (COVID-19): interim guidance. World Health Organization, 2020.

12. Wang, W., Xu, Y., Gao, R., Lu, R., Han, K., Wu, G., \& Tan, W. (2020). Detection of SARS-Cov-2 in different types of clinical specimens. JAMA. https://doi.org/ 10.1001/jama.2020.3786. https://doi.org/10.1001/ jama.2020.3786

13. Public Health England (2020). COVID 19: infection prevention and control guidance. https://www.gov.uk/ government/publications/wuhan-novel-coronavirusinfection-prevention-and-control/wuhan-novelcoronavirus-wn-cov-infection-prevention-and-control- 
BJM Vol. 31 No. 2

guidance\#mobile-healthcare-equipment (accessed 25/ 03/2020).

14. Van Doremalen, N., Bushmaker, T., Morris, D., Holbrook, M., Gamble, A., Williamson, B., Tamin, A., Harcourt, J., Thornburg, N., Gerber, S., Lloyd-Smith, J., De Wit, E., \& Munster, V. (2020). Aerosol and surface stability of hcov-19 (SARS-Cov-2) compared to SARSCov-1. https://doi.org/10.1101/2020.03.09. 20033217.

15. Gralton, J., Tovey, E., McLaws, M., \& Rawlinson, W. D. (2011). The role of particle size in aerosolised pathogen transmission: A review. Journal of Infection, 62(1), 113. https://doi.org/10.1016/j.jinf.2010.11.010. PMid:21094184 PMCid:PMC7112663

16. World Health Organization (2020). Clinical management of severe acute respiratory infection when novel coronavirus (nCoV) infection suspected. https:// www.who.int/publications-detail/clinicalmanagement-of-severe-acute-respiratory-infectionwhen-novel-coronavirus-(ncov)-infection-is-suspected (accessed 26/03/2020). https://doi.org/10.15557/ PiMR.2020.0003

17. European Centre for Disease Prevention and Control (2020). Infection prevention and control for COVID 19 in healthcare settings. https://www.ecdc.europa.eu/ en/publications-data/infection-prevention-andcontrol-covid-19-healthcare-settings (accessed 31/03/ 2020). https://doi.org/10.7748/cnp.19.3.12.s9

18. Public Health England (2020). When to use a surgical face mask or FFP3 respirator. https:// assets.publishing.service.gov.uk/government/ uploads/system/uploads/attachment_data/file/ 874411 /When_to_use_face_mask_or_FFP3.pdf (accessed 26/03/2020).
Hand hygiene and PPE during corona pandemic

19. Alhazzani, W., Møller, M. H., Arabi, Y. M., Loeb, M., Gong, M. N., Fan, E., Oczkowski, S., Levy, M. M., Derde, L., Dzierba, A., Du, B., Aboodi, M., Wunsch, H., Cecconi, M., Koh, Y., Chertow, D. S., Maitland, K., Alshamsi, F., Belley-Cote, E., ... Rhodes, A. (2020). Surviving sepsis campaign: Guidelines on the management of critically ill adults with coronavirus disease 2019 (COVID-19). Critical Care Medicine, 48(6), e440-e469. https:// doi.org/10.1097/ccm.0000000000004363. https:// PMid:32224769 PMCid:PMC7176264

20. Ran, L., Chen, X., Wang, Y., Wu, W., Zhang, L., \& Tan, X. (2020). Risk factors of healthcare workers with corona virus disease 2019: A retrospective cohort study in a designated hospital of Wuhan in China. Clinical Infectious Diseases. https://doi.org/10.1093/cid/ ciaa287. PMid:32179890 PMCid:PMC7184482

21 Lu, W., Danni, Y., Xinlan, W., Yujuan, C., You, L., \& Huai, Y. (2014). Correlation between hand hygiene compliance and nosocomial infection in medical staff. Chinese Journal of Disinfection, 31(11), 1237-1238.

22. Sharma, A., Kalita, J. M., \& Nag, V. L. (2019). Screening for methicillin-resistant staphylococcus aureus carriage on the hands of healthcare workers: An assessment for hand hygiene practices. Indian Journal of Critical Care Medicine, 23(12), 590-592. https://doi.org/10.5005/ jp-journals-10071-23296. PMid:31988552 PMCid:PM C6970211

23. Ranney, M. L., Griffeth, V., \& Jha, A. K. (2020). Critical supply shortages - The need for ventilators and personal protective equipment during the COVID-19 pandemic. New England Journal of Medicine, 382(18), e41. https: / /doi.org/10.1056/nejmp2006141. PMid:32212516. 